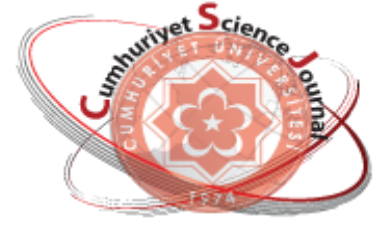

e-ISSN: 2587-246X

ISSN: 2587-2680

\section{Cumburiy at Scioneajononal}

esj

Cumhuriyet Sci. J., Vol.39-3(2018) 779-790

\title{
Preparationand Characterization of pH-Sensitive Hydrogels Based on Crosslinked Maleic Anhydride-Styrene-Methyl Methacrylate Terpolymer
}

\author{
Dilek IMREN KOÇ ${ }^{*}$, Saliha Esra BOLSU ${ }^{I}$, Hasan Hüseyin DURMAZUÇAR ${ }^{I}$, \\ Ali BOZTUG $\breve{G}^{2}$ \\ ${ }^{1}$ Cumhuriyet University, Chemical Engineering Department, Sivas, TURKEY \\ ${ }^{2}$ Cumhuriyet University, Chemistry Department, Sivas, TURKEY
}

Received: 13.04.2017; Accepted: 20.09.2018

http://dx.doi.org/10.17776/csj.462710

\begin{abstract}
In this study, the hydrogels have been synthesized by the crosslinking reactions maleic anhydridestyrene-methyl methacrylate terpolymer with $N, N^{\prime}$-methylene-bis-acrylamide and glutaraldehyde in various crosslinker ratios. Crosslinking reactions were carried out in the presence of tetrahydrofuran as solvent at 25$50^{\circ} \mathrm{C}$ for different time period, and the resulting material properties compared. The best conditions for effective crosslinking, i.e., crosslinking temperature, time and crosslinker ratios were determined for each crosslinker type. The swelling behaviour of the hydrogels was examined in Tris-buffer solutions at various $\mathrm{pH}$ at $37^{\circ} \mathrm{C}$. Swelling depending on $\mathrm{pH}$ was observed in the hydrogels. The $\mathrm{pH}$-dependent swelling of hydrogels was strongly influenced by the functional group of crosslinker. The molecular structure of the hydrogels was studied by Fourier Transform Infrared Spectroscopy and their pore structure was investigated by using Scanning Electron Microscope.
\end{abstract}

Keywords: Maleic anhydride-styrene-methyl methacrylate terpolymer, crosslinking, $N, N^{\prime}$-methylene-bisacrylamide, glutaraldehyde, $\mathrm{pH}$-sensitive hydrogels.

\section{Çapraz Bağlı Maleik Anhidrit-Stiren-MetilMetakrilat Terpolimerine Dayalı pH-Duyarlı HidrojellerinHazırlanması ve Karakterizasyonu}

\footnotetext{
Özet.Bu çalışmada; hidrojeller, maleikanhidrit-stiren-metilmetakrilat terpolimerinin $N, N$ 'metilenbisakrilamid ve glutaraldehitin farklı oranları ile çapraz bağlanmasıyla sentezlenmiştir. Çapraz bağlanma reaksiyonları çözücü olarak tetrahidrofuran varlığında farklı zaman periyodunda $25-50^{\circ} \mathrm{C}$ aralığında gerçekleştirilmiş ve malzeme özellikleri kıyaslanmıştır. Her bir çapraz bağlayıcı tipi için çapraz bağlanma sıcaklığı, zamanı ve çapraz bağlayıcı oranı gibi etkin çapraz-bağlanma koşulları belirlenmiştir. Hidrojellerin şişme davranışı Tris tampon ortamlarda farklı $\mathrm{pH}$ aralığında $37^{\circ} \mathrm{C}$ 'de incelenmiştir. Hidrojellerin $\mathrm{pH}$-duyarlı olduğu ve pH'ya bağlı şişmenin çapraz bağlayıcının fonksiyonel grubundan etkilendiği görülmüştür. Hidrojellerin moleküler yapısı Fourier Transform Infrared Spektroskopisi ile, gözenekyapısı da taramalı electron mikroskobu ile incelenmiştir.
}

AnahtarKelimeler:Maleikanhidrit stiren metilmetakrilat terpolimer, çaprazbağlanma, $N, \quad N^{\prime}$-metilen-bisakrilamid, glutaraldehit, $\mathrm{pH}$-duyarlı hidrojel. 


\section{INTRODUCTION}

Hydrogels are the three-dimensional, hydrophilic, polymeric network structures being able to absorb much more water or biological liquids than their own weight. They are non-soluble due to the existence of chemical or physical cross-links between main chains. Some hydrogels are stimulisensitive: they change their volume or shape in response to environmental changes such as temperature, $\mathrm{pH}$, ionic strength and magnetic field[1-4]. Among these stimuli-sensitive hydrogels, pH-sensitive hydrogels have been widely used in specific applications such as drug delivery[5-9], biotechnology and waste water treatments[10,11].

Terpolymers are polymeric structures that takes much interest in the studies relating to improving the properties of polymer blends[12, 13], polymeric biomaterials[14-18]and advanced separation systems[19, 20]due to the distribution of different functional groups. In addition terpolymers offer a great potential to develop to stimuli-sensitive hydrogels which combine two or more stimuli-sensitive mechanisms[4].

In literature many terpolymer formulations have been reported to form well-characterized stimulisensitive hydrogels. As examples: Bajpai and Dubey (2004) developed a pH-sensitive terpolymeric hydrogel system based on acrylamide (AAm), methacrylamide (MAm) and acrylic acid (AAc) by aqueous polymerization[21]. Gümüşderelioğlu and Topal (2005) synthesized pH-sensitive hydrogels by crosslinking of monomer mixtures containing ethylene glycol vinyl ether (EGVE), butyl vinyl ether (BVE) and acrylic acid (AA) in the presence of crosslinking agent diethylene glycol divinyl ether (DEGDVE)[22]. Paris et al. (2009) prepared terpolymeric hydrogels based on $\mathrm{N}$ isopropylacrylamide $(N$-iPAAm), methacrylic acid (MAA) and poly(ethylene glycol) monomethyl ether monomethacrylate macro monomer (PEGMEMA) and investigated their pH-sensitivity[23]. Reinicke et al. (2009) synthesized double stimuli-sensitive poly(2vinylpyridine)-block-poly(ethyleneoxide)-blockpoly(glycidyl methyl ether-co-ethyl glycidyl ether) (P2VP- $b$-PEO- $b$-P(GME-co-EGE) terpolymeric hydrogels by means of sequential anionic polymerization[24]. Akperov et al. (2009) modified maleic anhydride-allyl propionate- styrene terpolymer with tri-ethanolamine in order to prepare a new cross-linked functional polymer sorbent[10]. Ngadaonye et al. (2011) fabricated thermo-sensitive terpolymer hydrogels based on $\mathrm{N}$-tert-butylacrylamide (NtBAAm), $\mathrm{N}$ isopropylacrylamide (NIPAAm) and $N$-vinyl pyrrolidone (NVP) monomers via UV polymerization[25]. Micic et al. (2012) synthesized a series of dual $(\mathrm{pH}$ and thermo) sensitive terpolymeric hydrogels with different mole fractions of 2-hydroxyethyl methacrylate (HEMA), itaconic acid (IA) and oligo(ethylene glycol) acrylates (OEGA) by gamma radiation[26]. Yin et al. (2015) prepared slightly crosslinked monodisperse poly(maleic anhydridecyclohexyl vinyl ether-divinylbenzene) (MACHVE-DVB) microspheres via precipitation polymerization using 2,2-azobisisobutyronitrile as an initiator in a mixture of methyl ethyl ketone and n-heptane[27]. However, there is a limited amount of research dealing with the preparation of terpolymer-hydrogels containing maleic anhydride (MA)[10,27]. Meanwhile, terpolymers and terpolymer based hydrogels continue to be important materials for drug delivery, biotechnology and medical applications. We studied the synthesis of maleic anhydride-styrenemethyl methacrylate (MA-St-MMA) terpolymer based hydrogels by direct crosslinking with $N, N^{\prime}$ methylene-bis-acrylamide (MBAm) and glutaraldehyde (GA) to obtain a new type of $\mathrm{pH}$ sensitive hydrogel.

\section{EXPERIMENTAL}

\subsection{Materials}

Methyl methacrylate (MMA, bp: $100^{\circ} \mathrm{C}$ ) and Styrene (St, bp: $138^{\circ} \mathrm{C}$ ) were purchased from Merck (Germany). Maleic Anhydride (MA, bp: $200^{\circ} \mathrm{C}$ ) was obtained from Sigma-Aldrich (Germany). Azobisisobutyronitrile (AIBN) used as the free radical initator was supplied by SigmaAldrich (Germany). $\quad N, \quad N^{\prime}$-methylene-bisacrylamide (MBAm) and glutaraldehyde (GA) were obtained from Sigma-Aldrich (Germany). Tetrahydrofuran (THF, bp: $67^{\circ} \mathrm{C}$ ) used as the solvent was purchased from Prolabo (France). Hydrochloric acid (37\%) and 2-amino-2hydroxymethyl-1,3-propanediol (Tris) used in the swelling studies were supplied by Sigma-Aldrich (Germany). All chemicals were of analytical grade and were used as received. 


\subsection{Synthesis of the MA-St-MMA terpolymer hydrogels}

Terpolymerization reaction of MA-St-MMA taking the mole proportions of 2: 1: 1 ternary systems was carried out in the presence of AIBN as initator at $70^{\circ} \mathrm{C}$ for 1 hour. The terpolymer was precipitated in ethyl alcohol and then dried at $37^{\circ} \mathrm{C}$ in a vacuum and its composition was determined by FTIR[28]. In the second stage the terpolymer hydrogels were synthesized by crosslinking reaction of MA-St-MMA terpolymer in THF medium in the presence of MBAm or GA at $25-50^{\circ} \mathrm{C}$. The crosslinking agent was added to the terpolymer solution in different crosslinker ratios (i.e., mass of crosslinker/mass of terpolymer), and stirred magnetically for $15 \mathrm{~min}$. The polymer mixture was then poured into the Pyrex test tube (diameter $=6 \mathrm{~mm}$ ) and placed into an incubator (Nüve FN 055, Turkey) with appropriate time-temperature program. The resulting hydrogels were carefully removed from the test tubes and washed with distilled water to remove any impurities. Washed hydrogels were dried until constant weight in vacuum at $25^{\circ} \mathrm{C}$.

\subsection{Swelling studies}

In order to determine swelling ratio of hydrogels, each dried hydrogel sample was immersed in Tris buffer solutions of different $\mathrm{pH}(2.0-9.0, I=0.2)$ at $37^{\circ} \mathrm{C}$. The hydrogel was weighed every $30 \mathrm{~min}$ after drying the surface. Measurements were taken until a constant weight was reached. The swelling ratio, $S R$, was calculated by applying the following equation:

$$
S R=\left[\frac{M t-M o}{M o}\right]
$$

where, $M t$ and $M o$ represent the weights of swollen and dry samples, respectively.

\subsection{FTIR analysis}

The FTIR analysis was performed to identify the molecular structure of the hydrogels. The vacuumdried samples were mixed with $\mathrm{KBr}$ and pressed into pellets under hydraulic press force. The spectra were collected on a Mattson 1000 FTIR spectrophotometer at the wavelength range of $400-4000 \mathrm{~cm}^{-1}$ with a resolution of $4 \mathrm{~cm}^{-1}$.

\subsection{SEM analysis}

The synthesized hydrogels were examined using a scanning electron microscope (SEM) (LEO 440) in order to characterize the morphology. The samples were freeze-dried and fractured. The fractured surface was coated with gold-palladium under vacuum.

\section{RESULTS AND DISCUSSION}

\subsection{Preparation of MA-St-MMA terpolymer hydrogels}

MA-St-MMA terpolymer hydrogels were prepared by crosslinking of MA-St-MMA terpolymer with organic functional crosslinking agents MBAm and GA. The ring-opening reaction of MA units with MBAm resulted in the formation of crosslinked polymer with carboxylic groups and ester bonds.

In order to study the effect of crosslinker ratios on hydrogel formation, MA-St-MMA terpolymer hydrogels with different crosslinker ratios were prepared and characterized. MA-St-MMA / crosslinker mixtures containing less than 10\% crosslinker (wt \%) do not lead to the stable hydrogel formation. This is why, MA-St-MMA terpolymer hydrogels were prepared by varying crosslinker ratios from 10 to $40 \%$.

The curing time and step by step increase of reaction temperature are important for the completion of the crosslinking reaction[2]. In this study to establish crosslinking, rather drastic conditions (appropriate time-temperature program, crosslinker ratio) have to be applied. Our results showed that the reaction temperature has a strong effect on the completion of MA-St-MMA terpolymer/crosslinker reactions, and the applied time-temperature program increased the mechanical stability of the hydrogels. It was therefore decided to realize the crosslinking reactions with an appropriate time-temperature program by depending upon crosslinker type. For MBAm: $2 \mathrm{~h}$ at $25^{\circ} \mathrm{C}, 24 \mathrm{~h}$ at $37^{\circ} \mathrm{C}$; for GA:2 $\mathrm{h}$ at $25^{\circ} \mathrm{C}, 24 \mathrm{~h}$ at $37^{\circ} \mathrm{C}$, and $24 \mathrm{~h}$ at $50^{\circ} \mathrm{C}$.

\section{2. pH-sensitivity of the hydrogels}

The chemical structure of the polymer affects the swelling ratio of the hydrogels which is directly related to hydrogel application. The chemical structure depended upon composition of the 
polymeric matrix i.e. the crosslinker ratio. Highly crosslinked hydrogels that have a tighter structure will swell less as compared to the same hydrogels with lower crosslinking ratios[5]. This is why experiments to determine the $\mathrm{pH}$-dependent swelling behaviour were performed by depending upon the nature and ratio of crosslinker in
Trisbuffer solutions which have various $\mathrm{pHs}$ between 2 and 9 at $37^{\circ} \mathrm{C}$. The kinetic curves of swelling for the MA-St-MMA/MBAm and MASt-MMA/GA hydrogels containing about $10-40 \%$ $\mathrm{w} / \mathrm{w}$ crosslinker are illustrated respectively in Figures 1 and 2(a-d).
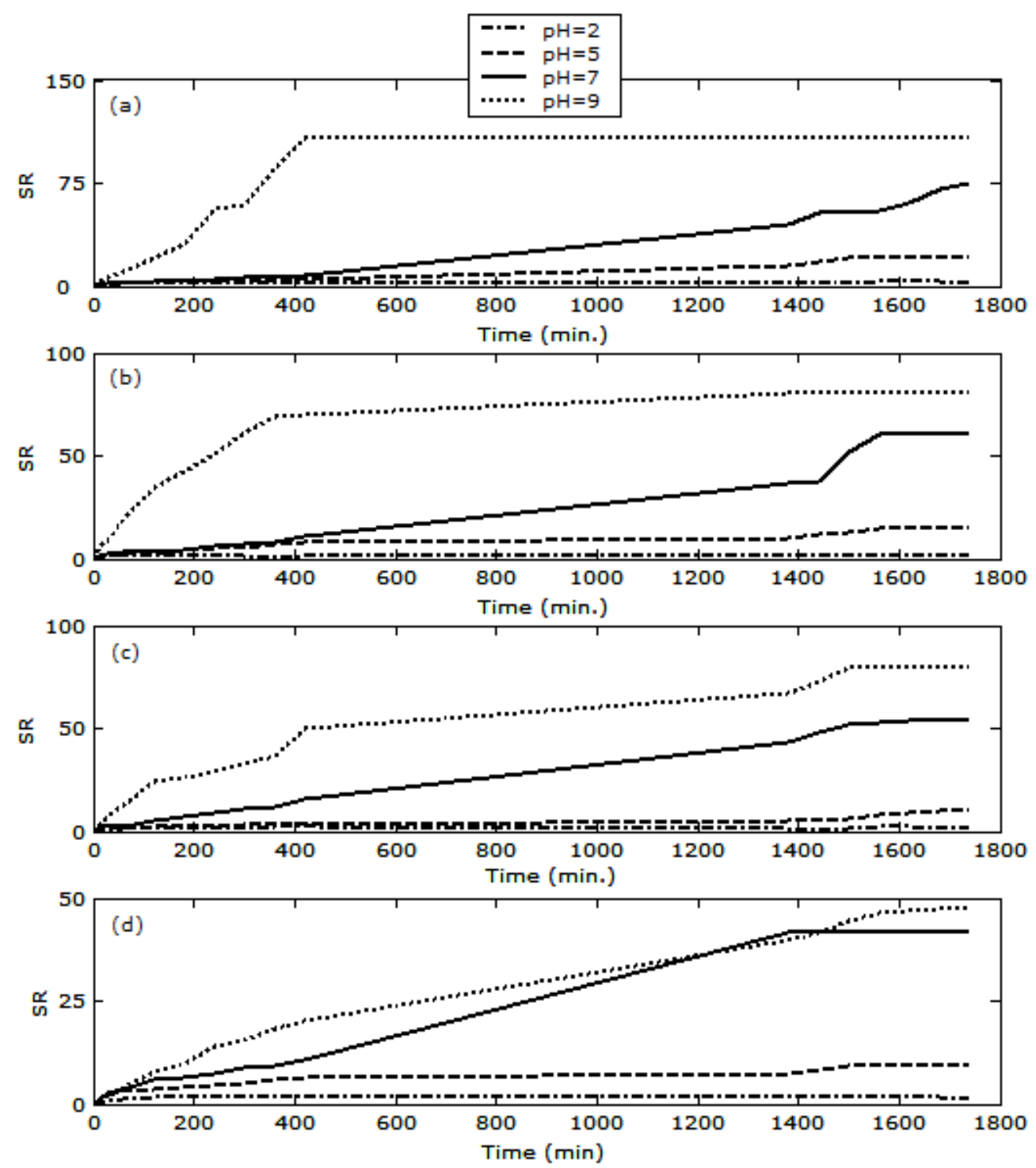

Figure 1. SR values of MA-St-MMA/MBAm hydrogels as a function of swelling medium $\mathrm{pH}$. (a) MA-St-MMA/MBAm (10\%) hydrogel, (b) MA-St-MMA/MBAm (20\%) hydrogel, (c) MA-St-MMA/MBAm (30\%) hydrogel, and (d) MA-StMMA/MBAm (40\%) hydrogel. 

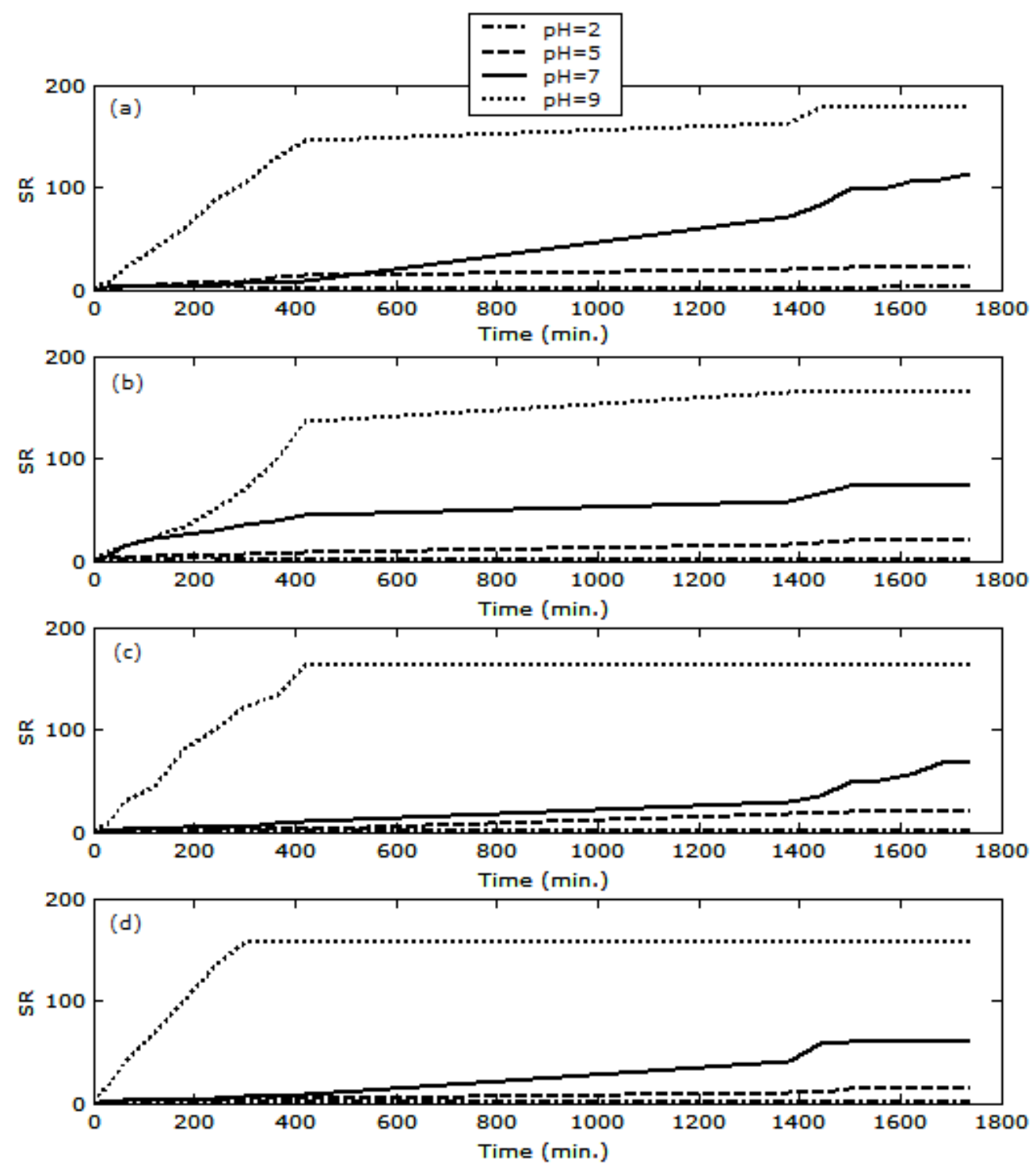

Figure 2. SR values of MA-St-MMA/GA hydrogels as a function of swelling medium $\mathrm{pH}$. (a) MA-St-MMA/GA (10\%) hydrogel, (b) MA-St-MMA/GA (20\%) hydrogel, (c) MA-St-MMA/GA (30\%) hydrogel, and (d) MA-St-MMA/GA (40\%) hydrogel.

As clearly seen in Figures 1 and 2 (a) - (d), the SR values of MA-St-MMA hydrogels were higher at basic medium than acidic medium, and there was a change swelling behavior of the hydrogels in response to $\mathrm{pH}$ change. These observations were taken as an indicator of that hydrogels exhibit $\mathrm{pH}$ sensitive swelling behavior.
It is also shown that the SRs of all hydrogels were increased by time, but after a certain period they show constant swelling (Figures 1 and 2(a)-(d)). This constant value may be called equilibrium swelling ratio (ESR). The determination of ESR has great practical significance and it was realized by eq. (1). The ESR values were given in Table I together with the crosslinker ratios. 
Table 1. Equilibrium swelling ratios of the MA-St-MMA-crosslinker systems in different $\mathrm{pHs}$ at $37^{\circ} \mathrm{C}$.

\begin{tabular}{lccccc}
\hline \multicolumn{1}{c}{$\begin{array}{c}\text { Hydrogel } \\
\text { Type }\end{array}$} & $\begin{array}{c}\text { Crosslinker } \\
\text { Ratio } \\
\text { \% (w/w) }\end{array}$ & $\mathrm{pH} \mathrm{2}$ & $\mathrm{pH} \mathrm{5}$ & $\begin{array}{c}\text { ESR Values } \\
\mathrm{pH} \mathrm{7}\end{array}$ & $\mathrm{pH} \mathrm{9}$ \\
\hline MA-St-MMA/MBAm & 10 & 1.92 & 20.71 & 75.45 & 107.98 \\
MA-St-MMA/MBAm & 20 & 1.60 & 14.59 & 61.41 & 80.90 \\
MA-St-MMA/MBAm & 30 & 1.56 & 10.14 & 53.40 & 79.15 \\
MA-St-MMA/MBAm & 40 & 1.38 & 9.43 & 41.47 & 47.29 \\
MA-St-MMA/GA & 10 & 1.95 & 22.71 & 112.67 & 177.70 \\
MA-St-MMA/GA & 20 & 1.68 & 19.49 & 73.50 & 165.00 \\
MA-St-MMA/GA & 30 & 1.59 & 19.14 & 67.61 & 163.17 \\
MA-St-MMA/GA & 40 & 1.43 & 13.57 & 61.20 & 157.46 \\
\hline
\end{tabular}

As seen in Table 1, the ESR values of MA-StMMA hydrogels containing $10 \%$ crosslinker were higher than those with crosslinker ratios of $20 \%$, $30 \%$, and $40 \%$ in all $\mathrm{pH}$ values. For example for $\mathrm{pH}$ 9, the ESR values of MA-St-MMA/MBAm hydrogels containing 10 and $40 \%$ MBAmcrosslinker were respectively $108 \pm 1$ and $47 \pm 1$. However the ESR values of MA-StMMA/GA hydrogels are higher than MA-StMMA/MBAm in all studied $\mathrm{pH}$ values. These differences among the swelling properties of MASt-MMA hydrogels might be attributed to the different functional groups of crosslinkers.

These results clearly demonstrate that the maximum water uptake was observed at $10 \%$ crosslinker ratio then it begins to decrease with further increase in crosslinker content. This is probably due to the reduction in the mesh size of the gel on raising the crosslinker content, which slows down the diffusion rate of water molecules out of the gel phase.

The results obtained allow to simply reflect the possibility of the formation of terpolymeric hydrogel with different swelling properties and functionality in the MA-St-MMA/crosslinker systems.

\subsection{FTIR characterization}

The ring-opening reaction of MA units with crosslinkers (MBAm and GA) resulted in the formation of crosslinked polymers with carboxylic groups and ester bonds. FTIR spectra of MA-St-MMA terpolymer and MA-St-MMA hydrogels were presented in Figure 3. Peaks related to $\mathrm{O}=\mathrm{C}-\mathrm{O}-$ $\mathrm{C}=\mathrm{O}$ ring stretching vibrations of a saturated cyclic five membered anhydride (at $952-909 \mathrm{~cm}^{-1}$ ) were clearly seen in the IR spectrum of MA-StMMA terpolymer. As expected, the conversion of cyclic anhydride to carboxylic and ester groups after the cross-linking reactions, increased the carboxyl and ester group absorption intensities in a range of 1700-1727 $\mathrm{cm}^{-1}$ (for MA-StMMA/MBAm and MA-St-MMA/GA hydrogels). Theabsorptionband at $1735 \mathrm{~cm}^{-1}$ can be assignedto MMA groups in theterpolymer. It is importanttonoticethatwhenthe MMA amount is decreased (forthehydrogels), theintensity of theabsorptionband is alsodecreased. These FTIR studies indicated that crosslinking occurs through the ring opening reaction of MA units with crosslinkers (MBAm and GA). 


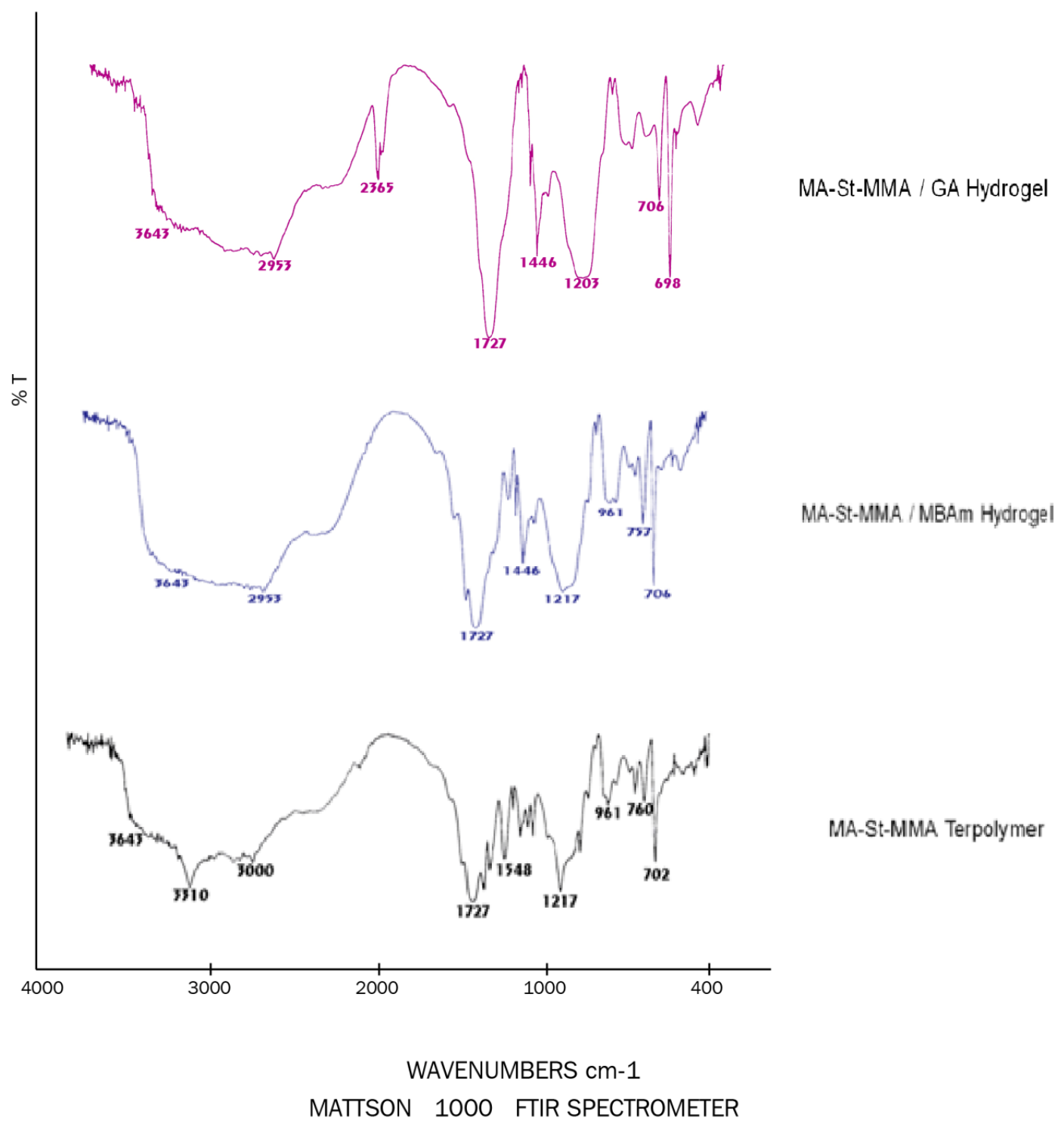

Figure 3. FTIR spectra of MA-St-MMA terpolymer, MA-St-MMA/MBAm and MA-St-MMA/GA hydrogels (40\%).

\subsection{Morphological analysis by SEM}

SEM provides information about morphology of the hydrogel network. SEM pictures were taken at the surfaces and cross sections of the MA-St-MMA hydrogels for this purpose. These pictures were presented in Figures 4(a-c) and 5(a-c) for MA-St-MMA/MBAm and MA-St-MMA/GA hydrogels, respectively. 


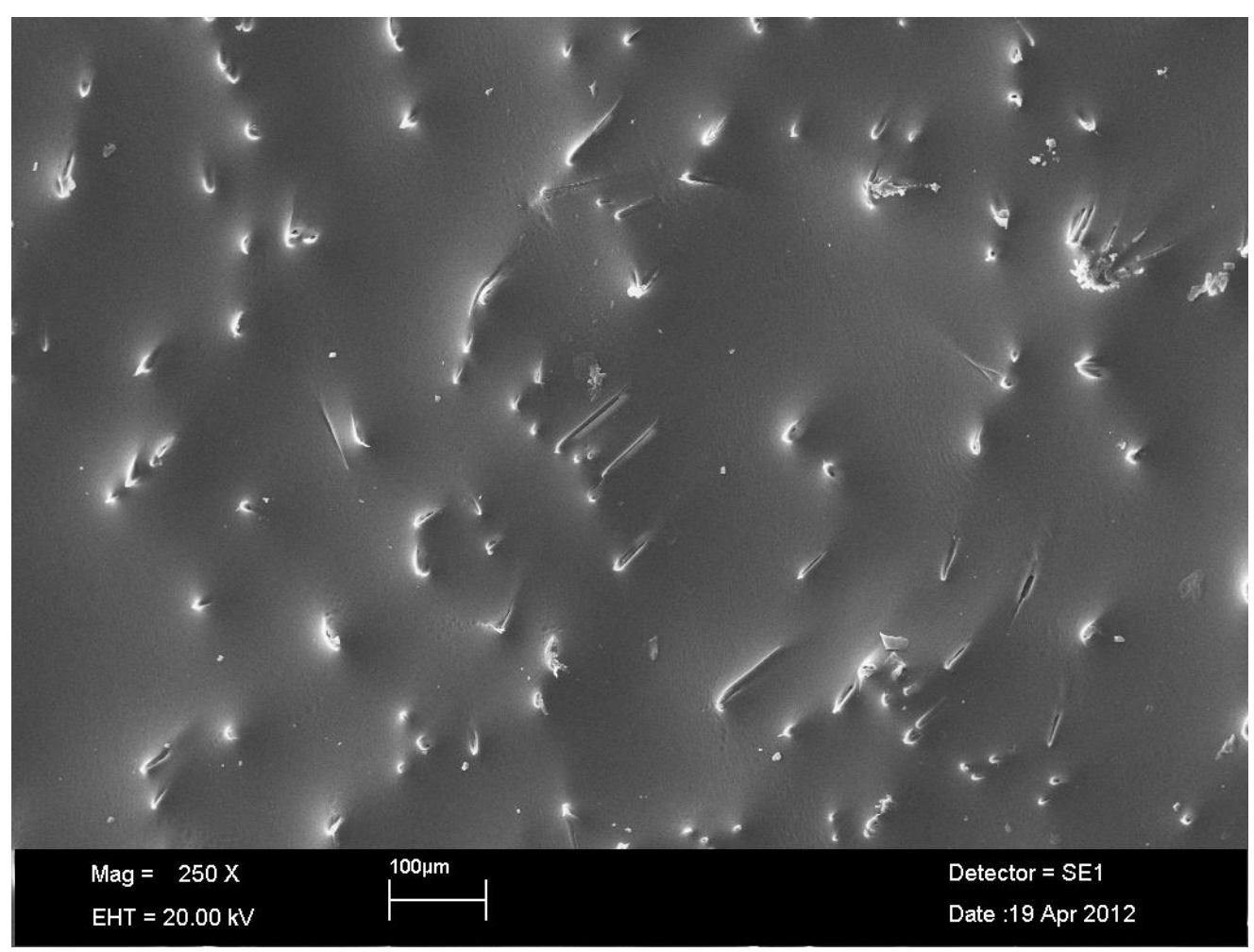

(a)

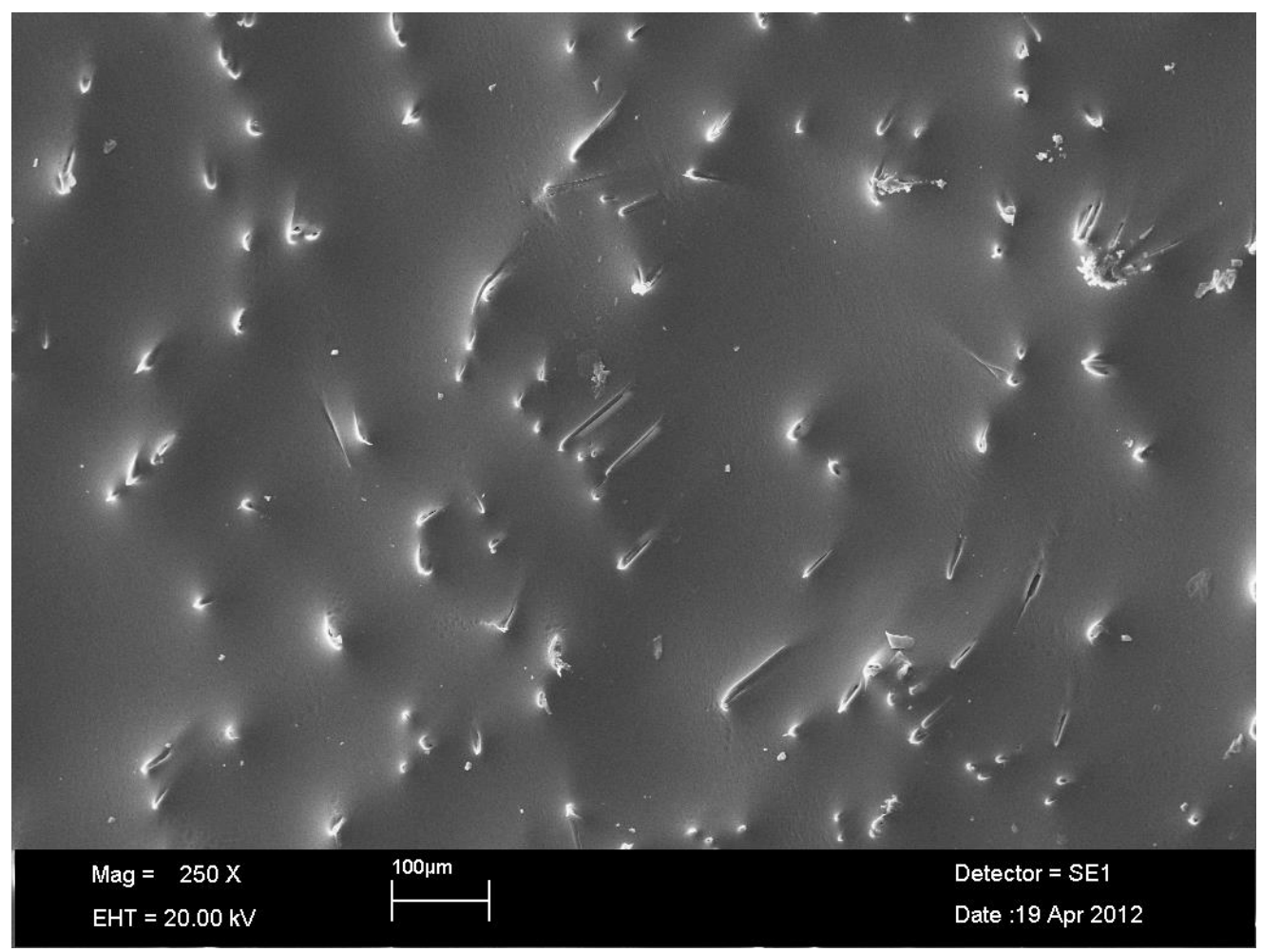

(b) 


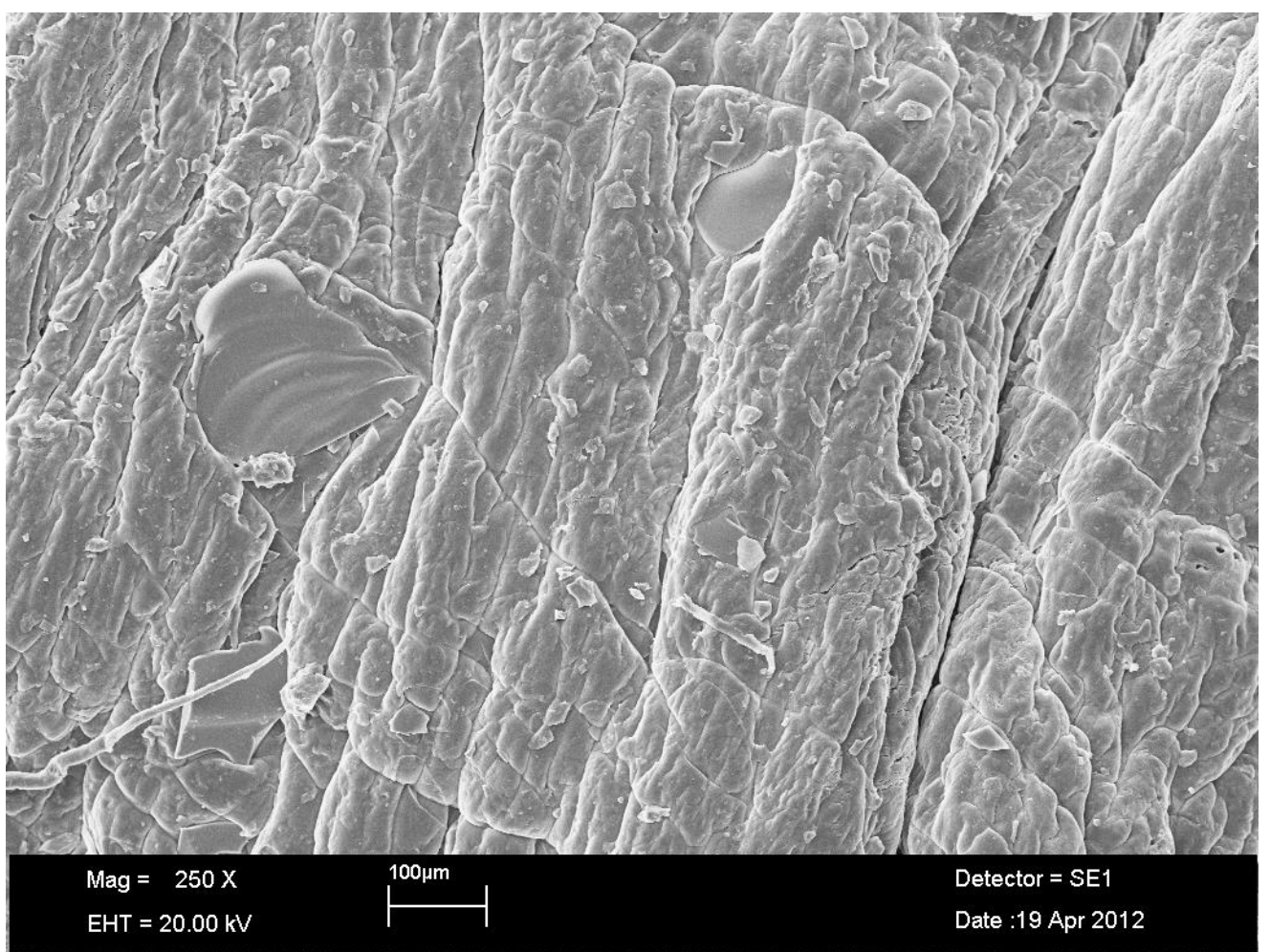

(c)

Figure 4. SEM images of MA-St-MMA/MBAm(40\%) hydrogel: (a) a general view from surface (magnification $=250 x$ ), (b) a general view from surface of the same hydrogel (magnification $=650 x$ ), and $(c)$ a cross section of the same hydrogel $($ magnification $=250 x)$.

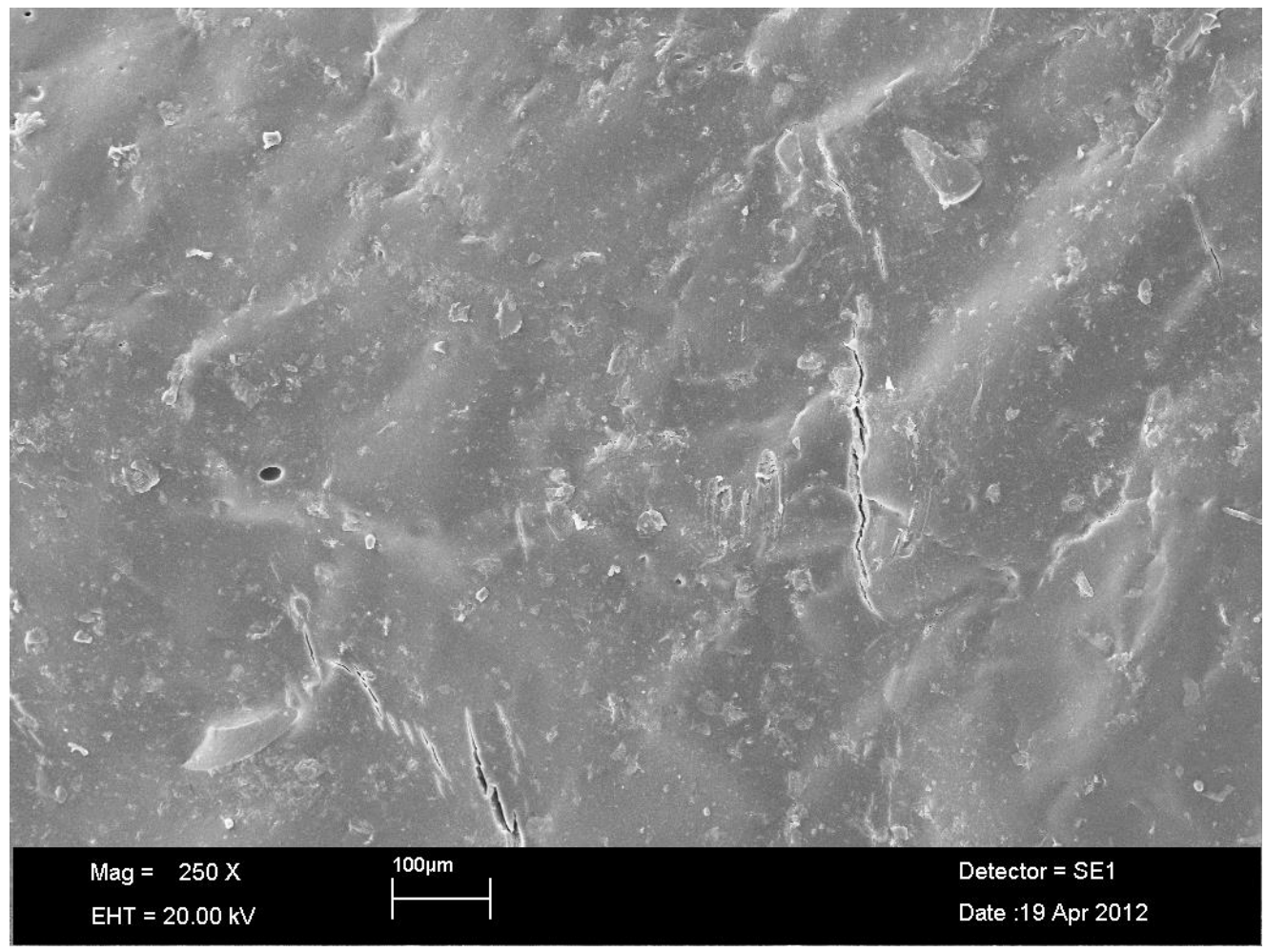

(a) 


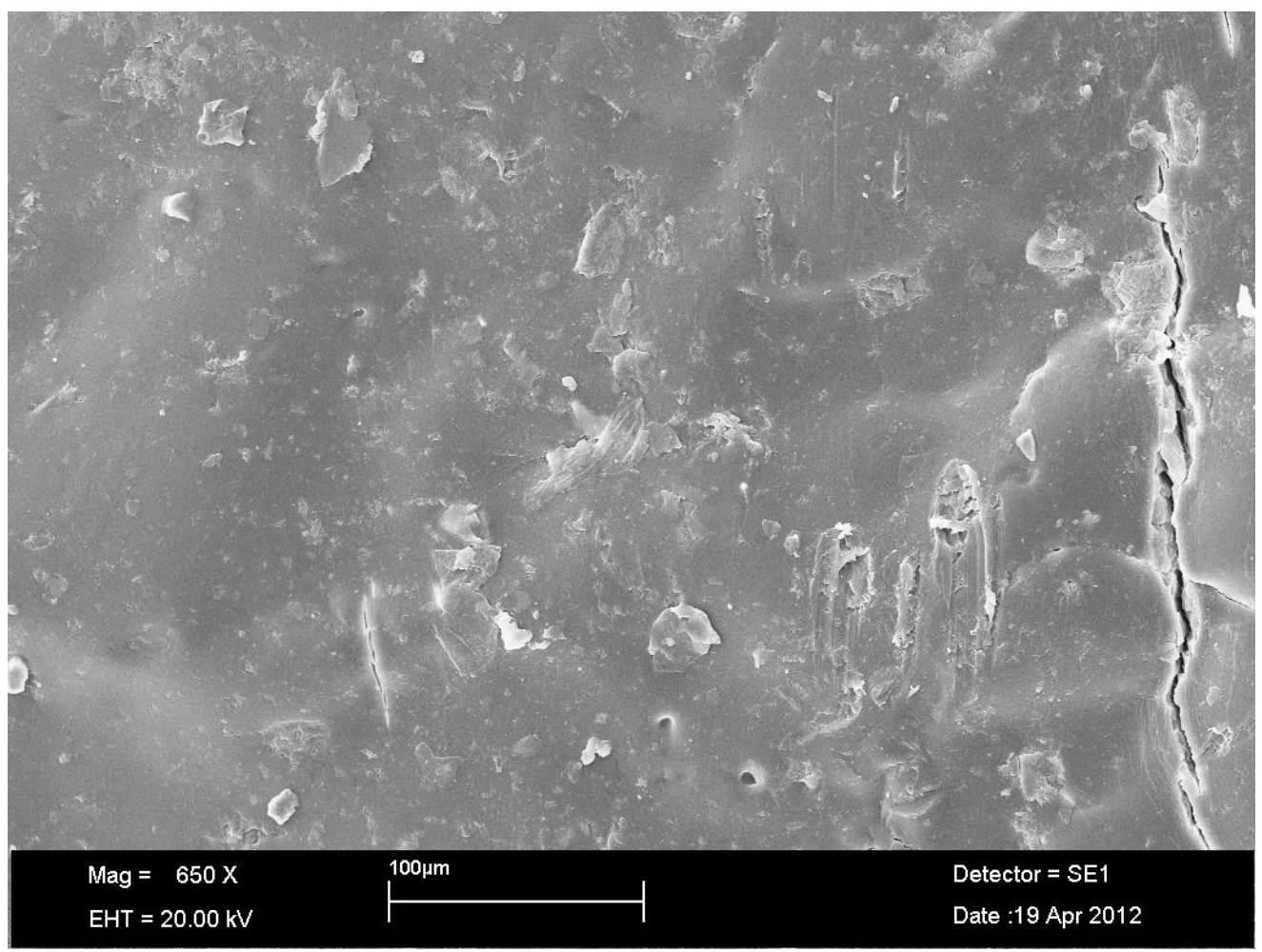

(b)

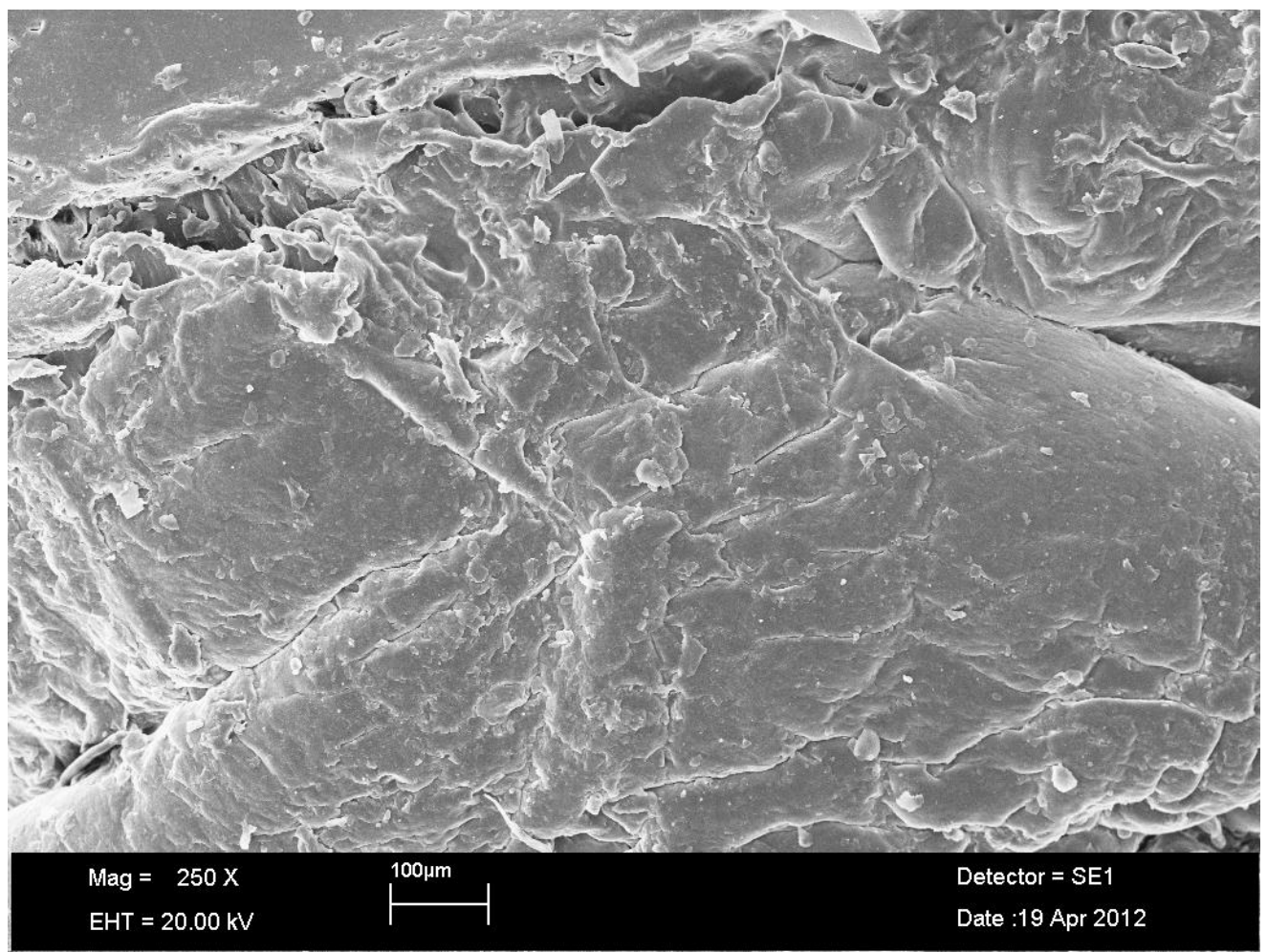

(c)

Figure 5. SEM images of MA-St-MMA/GA (40\%) hydrogel: (a) a general view from surface (magnification $=250 \mathrm{x}$ ), (b) a general view from surface of the same hydrogel (magnification $=650 \mathrm{x}$ ), and $(\mathrm{c})$ a cross section of the same hydrogel (magnification $=250 \mathrm{x})$. 
Figures $4(\mathrm{a}-\mathrm{b})$ and $5(\mathrm{a}-\mathrm{b})$ show surface images from hydrogels with different crosslinkers (MBAm and GA,respectively). In the case of MASt-MMA/GA hydrogels, the structure becomes less ordered and more porous(Figures 5 (a-b)). Figures 4 (c) and 5 (c) present cross-sectional view of the MA-St-MMA/MBAm and MA-StMMA/GA hydrogels, respectively at a magnification of $250 x$. It is possible to see that MA-St-MMA/GA hydrogels are covered by irregular pores with size ranging $5-10 \mu \mathrm{m}$ (Figure $5(\mathrm{c}))$ by using imageJ software.

\section{CONCLUSION}

In this study, MA-St-MMA terpolymer based hydrogels were prepared by crosslinking of MASt-MMA terpolymer with organic functional crosslinkingagentsMBAmand GA. The appropriate time-temperature program was found to realize the crosslinking reactions for all studied MA-St-MMA/crosslinker systems. From the swelling studies of the hydrogels as a function of crosslinker ratio and $\mathrm{pH}$, it is concluded that the hydrogels exhibit significantly $\mathrm{pH}$-sensitive swelling behaviour. The proposed hydrogel system bears the potential to be used for specific applications such as drug delivery, biotechnology and waste water treatments.

\section{REFERENCES}

[1]. Qiu Y., Park K., Environment-sensitive hydrogels for drug delivery, Adv. Drug Del. Rev.53 (2001) 321-339.

[2]. İmren D., Gümüşderelioğlu M., Güner A., Synthesis and characterization of dextran hydrogels prepared with chlor- and nitrogencontaining crosslinkers, J. Appl. Polym. Sci. 102 (2006) 4213-4221.

[3]. Dispenza C., Tripodo G., LoPresti C., Spadaro G., Giammona G., Synthesis, characterisation and properties of $\alpha, \beta$ poly(N-2-hydroxyethyl)-DL-aspartamide-

graft-maleic anhydride precursors and their stimuli-responsive hydrogels, React. Funct. Polym. 69 (2009) 565-575.

[4]. Alzari V., Ruiu A., Nuvoli D., Sanna R., Martinez J.I., Appelhans D., Voit B., Zschoche S., Mariani A., Three component terpolymer and IPN hydrogels with response to stimuli, Polymer 55 (2014) 5305-5313.

[5]. Singh B., Chauhan G.S., Kumar S., Chauhan N., Synthesis, characterization and swelling responses of $\mathrm{pH}$ sensitive psyllium and polyacryamide based hydrogels for the use in drug delivery (I), Carbohydr.Polym.67 (2007) 190-200.

[6]. İmren D., Gümüşderelioğlu M., Güner A., In vitro release kinetics of bovine serum albumin from highly swellabledextran hydrogels, J. Appl. Polym. Sci.115 (2010) 740-747.

[7]. Shalviri A., Chan H.K, Raval G., Abdekhodaie M.J., Liu Q., Design of pHresponsive nanoparticles of terpolymer of poly(methacrylic acid), polysorbate 80 and starch for delivery of doxorubicin, Colloids.Surf.B: Biointerfaces101 (2013) 405-413.

[8]. Xu Q., Huang W., Jiang L., Lei Z., Li X., Deng H., KGM and PMAA based pHsensitive interpenetrating polymer network hydrogel for controlled drug release, Carbohydr. Polym. 97 (2013) 565-570.

[9]. Koetting M.C.,Peppas N.A., pHResponsivepoly(itaconicacid-co-N-

vinylpyrrolidone)

hydrogelswithreducedionicstrengthloadingsol utionsofferimproved oral deliverypotentialforhighisoelectricpointexhibitingtherapeuticproteins, Int. J.Pharm.471 (2014) 83-91.

[10].Akperov E.O.,Maharramov A.M., Akperov O.G., Uranyl ion adsorption using novel cross-linked maleic anhydride-allyl propionate-styrene terpolymer, Hydrometallurgy 100 (2009) 76-81.

[11].Dalaran M., Emik S., Güçlü G., İyim T.B., Özgümüş S., Removal of acidic dye from aqueous solutions using poly(DMAEMAAMPS-HEMA) terpolymer/MMT nanocomposite hydrogels, Polym. Bull.63 (2009) 159-171.

[12].İmren D., Boztuğ A., Yilmaz E., Zengin H.B., Viscometric investigation of compatibilization of the poly(vinyl chloride)/poly(ethylene-co-vinyl acetate) blends by terpolymer of maleic anhydridestyrene-vinyl acetate, J. Mol.Struct. 891 (2008) 329-332.

[13].İmren D., Compatibilization of immiscible poly(vinyl chloride)(PVC)/polystyrene (PS) 
blends with maleic anhydride-styrene-vinyl acetate terpolymer (MAStVA), J. Mol.Struct.963 (2010) 245-249.

[14].Arimoto M., Ichikawa H., Fukumori Y., Microencapsulation of water-soluble macromolecules with acrylic terpolymers by the wurster coating process for colon-specific drug delivery, Powder Technol. 141 (2004) 177-186.

[15].Rimmer S., German M.J., Maughan J., Sun Y., Fullwood N., Ebdon J., MacNeil S., Synthesis and properties of amphiphilic networks 3: preparation and characterization of block conetworks of poly(butyl methacrylate-block-(2,3 propandiol-1methacrylate-stat-ethandiol dimethacrylate)), Biomaterials 26 (2005) 2219-2230.

[16].Wilson J.T., Cui W., Sun X.L., Burden C.T, Weber C.J, Chaikof E.L., In vivo biocompatibility and stability of a substratesupported polymerizable membrane-mimetic film, Biomaterials 28 (2007) 609-617.

[17].Moshaverinia A., Roohpour N., Darr J.A., Rehman I.U., Synthesis and characterization of a novel $\mathrm{N}$-vinylcaprolactam-containing acrylic acid terpolymer for applications in glass-ionomer dental cements, ActaBiomater. 5 (2009) 2101-2108.

[18].Heath D.E., Cooper S.L., Design and characterization of sulfobetaine-containing terpolymer biomaterials, ActaBiomater. 8 (2012) 2899-2910.

[19].Cheng C., Ma L., Wu D., Ren J., Zhao W., Xue J., Sun S, Zhao C., Remarkable pHsensitivity and anti-fouling property of terpolymer blended polyethersulfone hollow fiber membranes, J. Membr. Sci. 378 (2011) 369-381.

[20].Li H., Liao J., Xiang T., Wang R., Wang D., Sun S., Zhao C., Preparation and characterization of $\mathrm{pH}$-and thermo-sensitive polyethersulfone hollow fiber membranes modified with p(NIPAAm-MAA-MMA) terpolymer, Desalination 309 (2013) 1-10.

[21].Bajpai S.K., Dubey S., Synthesis and swelling kinetics of a $\mathrm{pH}$-sensitive terpolymeric hydrogel system, Iran.Polym. J. 13:3 (2004) 189-203.

[22].Gümüşderelioğlu M., Topal I.U, Vinyl ether/acrylic acid terpolymer hydrogels synthesized by $\gamma$-radiation: characterization, thermosensitivity and $\mathrm{pH}$-sensitivity. Radiat. Phys. Chem. 73 (2005) 272-279.

[23].Paris R., Barrales-Rienda J.M, QuijadaGarrido I., Dynamic swelling of hydrogels based on random terpolymers of $\mathrm{N}$ isopropylacrylamide, methacrylic acid and poly(ethylene glycol) macromonomer, Polymer 50 (2009) 2065-2074.

[24].Reinicke S., Schmelz J., Lapp A., Karg M., Hellweg T., Schmalz H., Smart hydrogels based on double responsive triblock terpolymers, Soft Matter 5 (2009) 2648-2657.

[25].Ngadaonye J.I., Cloonan M.O., Geever L.M., Higginbotham C.L., Synthesis and characterization of thermo-sensitive terpolymer hydrogels for drug delivery applications, J. Polym. Res. 18 (2011) 23072324.

[26].Micic M., Stamenic D., Suljovrujic E., Radiation-induced synthesis and swelling properties of $\mathrm{p}$ (2-hydroxyethyl methacrylate/itaconic acid/oligo(ethylene glycol) acrylate) terpolymeric hydrogels, Radiat. Phys. Chem. 81 (2012) 1451-1455.

[27].Yin C., Xu A., Gong L., Zhang L., Geng B., Zhang S., Preparation of slightly crosslinked monodisperse poly(maleic anhydridecyclohexyl vinyl ether-divinylbenzene) functional microspheres with anhydride groups via precipitation polymerization, Particuology 19 (2015) 99-106.

[28].Boztuğ A., Basan S., Ekberov O.E., Characterization and synthesis of some alternating terpolymers of maleic anhydride, Mat. Res. Innovat., 8.2 (2004) 89-92. 